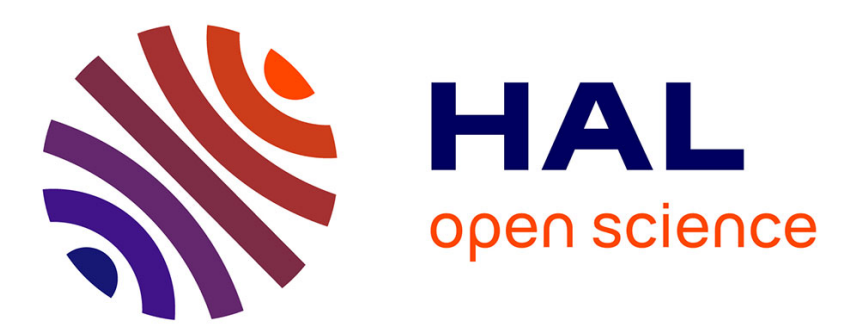

\title{
Trace element accumulation in relation to trophic niches of shorebirds using intertidal mudflats
}

Magali Lucia, Pierrick Bocher, Mélanie Chambosse, Philippe Delaporte, Paco

Bustamante

\section{- To cite this version:}

Magali Lucia, Pierrick Bocher, Mélanie Chambosse, Philippe Delaporte, Paco Bustamante. Trace element accumulation in relation to trophic niches of shorebirds using intertidal mudflats. Journal of Sea Research (JSR), 2014, 92 (C), pp.134 - 143. 10.1016/j.seares.2013.08.008 . hal-01079073

\section{HAL Id: hal-01079073 https://hal.science/hal-01079073}

Submitted on 31 Oct 2014

HAL is a multi-disciplinary open access archive for the deposit and dissemination of scientific research documents, whether they are published or not. The documents may come from teaching and research institutions in France or abroad, or from public or private research centers.
L'archive ouverte pluridisciplinaire HAL, est destinée au dépôt et à la diffusion de documents scientifiques de niveau recherche, publiés ou non, émanant des établissements d'enseignement et de recherche français ou étrangers, des laboratoires publics ou privés. 


\title{
Trace element accumulation in relation to trophic niches of shorebirds using intertidal mudflats
}

\author{
Magali Lucia $^{\mathrm{a}, *}$, Pierrick Bocher ${ }^{\mathrm{a}}$, Mélanie Chambosse ${ }^{\mathrm{a}}$, Philippe Delaporte ${ }^{\mathrm{b}}$, Paco \\ Bustamante $^{\mathrm{a}}$
}

a Littoral, Environnement et Sociétés (LIENSs), UMR 7266 CNRS-Université de La Rochelle, 2 rue Olympe de Gouges, 17000 La Rochelle, France.

${ }^{\text {b }}$ Ligue pour la Protection des Oiseaux LPO, Réserve Naturelle de Moëze-Oléron, Ferme de plaisance, 17780 Saint-Froult, France.

*Corresponding Author: Magali LUCIA

E-mail address: m.lucia33@laposte.net

FAX: $\quad+33546507663$

Phone: $\quad+33546457217$ 


\begin{abstract}
This study investigated the link between trace element concentrations and respective diets of two shorebird species present in the Pertuis Charentais, Atlantic coast of France: the Dunlin (Calidris alpina) and Redshank (Tringa totanus). Trace elements concentrations (Ag, As, Cd, $\mathrm{Co}, \mathrm{Cr}, \mathrm{Cu}, \mathrm{Fe}, \mathrm{Hg}, \mathrm{Mn}, \mathrm{Ni}, \mathrm{Pb}, \mathrm{Se}, \mathrm{Zn}$ ) were investigated in the liver, kidney, muscle and feathers of 28 dunlins and 15 redshanks accidentally dead during catches by mist net. Analyses of carbon and nitrogen stable isotope ratios were carried out in liver, muscle and feathers to determine whether differences in diet explained the variations in elemental levels. These results were compared to previous data obtained on two other shorebird species present on the same sites: the Black-tailed Godwit (Limosa limosa) and Red Knot (Calidris canutus). This study demonstrated that shorebirds of the Pertuis Charentais were characterized by differential trace element bioaccumulation. Arsenic and Se concentrations were elevated in red knots and dunlins, whereas redshanks displayed higher $\mathrm{Cd}$ concentrations in internal tissues. These trace element bioaccumulation discrepancies could mainly come from divergences of trophic habits between shorebirds. Species with the highest trophic position displayed the highest $\mathrm{Hg}$ concentrations in the liver, muscle and feathers demonstrating therefore the biomagnification potential of this metal, as opposed to $\mathrm{Cd}$ and $\mathrm{Pb}$. The same trend was observed in muscle and feathers for Se and only in feathers for As. These data highlighted the need to study several tissues to obtain a full comprehension of trace element exposure and pathways especially for long-distance migrating species using various habitats and sites.
\end{abstract}

Keywords Metal; Bioaccumulation; Shorebird; Stable isotopes 


\section{Introduction}

Coastal ecosystems ranks today among the most endangered ecosystems in the world due to human activities (Halpern et al., 2008; Vitousek et al., 1997). The degradation and/or the alteration of the habitats are partly the result of the massive dispersion of toxic compounds in environments (Nriagu, 1996). Among wild populations, $48 \%$ of shorebird species are declining due to the degradation and loss of habitats anywhere along their flyway (Delany and Scott, 2006, Stroud et al., 2006). Furthermore, birds exploiting intertidal systems are particularly vulnerable to contaminants because they are relatively long-lived species that bioaccumulate contaminants throughout their whole life and feed at the top of their food chain (Burger, 1993).

The Atlantic coast of France appears a central position on the East-Atlantic flyway of shorebirds between breeding sites in high latitudes like arctic area and/or in Northern Europe, and wintering area of Southern Europe and/or Western Africa (Delany et al., 2009). The Pertuis Charentais on the French central Atlantic coast are the major wintering sites for shorebirds in France (Mahéo, 2011). Among all the shorebird species present in this area, the Dunlin Calidris alpina has the highest numbers with more than 145,000 individuals present each year. Three subspecies encompassing five populations, C. a. alpina, C. a. schinzii, and C. $a$. arctica, have been identified in the area during wintering or stopover. In addition, this species is protected in France since 1981. The Redshank Tringa totanus encompasses three subspecies T. t. robusta, T. t. Britannica and T. t. totanus in Europe. In the Pertuis Charentais, c. 2,000 individuals are counted each mid-winter year. Both species use intertidal mudflats to feed on macrofaunal prey but they are able to switch their diet in various sites along their migratory pathways (Dierschke et al., 1999; Masero and Pérez Hutardo, 2001).

Despite its major role for stopover and wintering of shorebirds, the Pertuis Charentais also constitute a contaminated area. Indeed, this ecosystem is subject to increased inputs of some trace elements through the discharges of four important rivers, i.e. the Seudre, the Charente, the Sèvre Niortaise and the Gironde (Pigeot et al., 2006), which lead to subsequent bioaccumulation in the macrofaunal community (Bustamante and Miramand, 2004, 2005) and, therefore, in the prey of shorebirds. Consequently, shorebirds are exposed to different non-essential (and thus potentially toxic beyond a threshold) elements such as silver (Ag), cadmium $(\mathrm{Cd})$, lead $(\mathrm{Pb})$, and mercury $(\mathrm{Hg})$, and also essential elements that could be toxic at high levels such as arsenic (As), cobalt $(\mathrm{Co})$, chromium $(\mathrm{Cr})$, copper $(\mathrm{Cu})$, iron $(\mathrm{Fe})$, manganese (Mn), nickel (Ni), selenium (Se) and zinc ( $\mathrm{Zn})$. Trace element bioaccumulation of 
shorebirds has previously been reported in two distinct studies (Lucia et al., 2012ab) for the Black-tailed Godwit Limosa limosa which mainly feed on the bivalve Macoma balthica (Robin et al., in press) and the Red Knot Calidris canutus whose diet is mainly composed of the gastropod Hydrobia ulvae (Quaintenne et al., 2010). Importantly, in these two species, sublethal effects triggered by elements such as $\mathrm{Ag}, \mathrm{As}, \mathrm{Cd}, \mathrm{Cu}$, and Se were evidenced on genetic expression, enzymatic and protein levels. Specifically, the up-regulation of mitochondrial genes such as cytochrome c oxidase 1 in godwits presenting higher elemental concentrations tended to suggest that shorebirds feeding in the Pertuis Charentais might have additional energetic costs related to the detoxification of these contaminants (Lucia et al., 2012a).

In aquatic systems, food constitutes the major exposure route of waterbirds to trace elements. As of today, one of the main goals in ecotoxicology is therefore to investigate more precisely the trophic ecology of species to better understand exposure pathways and explain contaminant concentrations in animal populations. In this field, stable isotopes have provided an increasingly powerful means of linking wild animal populations to their diet and ultimate contaminant source (Jardine et al., 2006; Jarman et al., 1996). Furthermore, over the past decade stable isotopes have been validated in assessing the biomagnification potential of a variety of contaminants and in evaluating the exposure threat encountered by wildlife that rely on aquatic food webs as a source of food (Campbell et al., 2005; Quinn et al., 2003).

The first objective of the current study was therefore to investigate the trace element concentrations of two species of the local shorebird community: the Dunlin and Redshank and to compare these results to previous data obtained on two other abundant shorebird species: the Black-tailed Godwit and the Red Knot (Lucia et al., 2012ab). Consequently, the concentrations of the 13 trace elements cited above were determined in the liver, kidney, muscle and feathers of these shorebirds. The relation between trace element concentrations of each tissue was examined to highlight if concentrations in feathers reflect concentrations of internal tissues. The second aim of this study was to investigate the link between trace element concentrations and the respective diets of shorebird species of the Pertuis Charentais. Carbon $\left(\delta^{13} \mathrm{C}\right)$ and nitrogen $\left(\delta^{15} \mathrm{~N}\right)$ stable isotopes were therefore analysed in the liver, muscle and feathers of dunlins and redshanks and compared to previous data obtained in godwits and knots to investigate the effect of diet on trace element loads in shorebird species occupying similar habitats. 


\section{Material and methods}

\subsection{Study site and sampling}

On the French central Atlantic coast lies a huge network of estuarine bays and islands known as the "Pertuis Charentais" (N46 09', W1 $\left.{ }^{\circ} 09^{\prime}\right)$. The Pertuis Charentais are the main wintering and/or stopover sites during Spring and Autumn migration for shorebirds in France (Mahéo, 2011). Therefore, birds are monthly caught by mist net for ringing purposes. Of the 28,058 individuals caught belonging to the four species studied, 89 individuals accidentally died and were consequently used in the current study. Red Knot Calidris canutus $(\mathrm{n}=15)$, Black-tailed Godwit Limosa limosa $(\mathrm{n}=31)$, Dunlin Calidris alpina $(\mathrm{n}=28)$ and Redshank Tringa totanus $(\mathrm{n}=15)$ were collected between May 2003 and February 2011 at four sites in the Pertuis Charentais: Ré Island, Aiguillon Bay, Yves Bay and Marennes-Oléron Bay (Fig. 1). Data on trace element concentrations for godwits and knots have been previously published but were used in the present study in order to investigate and compare the patterns of bioaccumulation of the different species.

Whenever it was possible, sex and age class (juvenile/adult) were determined for each individual during the dissection. The liver, kidney, pectoral muscle and breast feathers were sampled, weighed to the nearest gram (wet weight, ww), placed in individual plastic bags and stored at $-20^{\circ} \mathrm{C}$. Liver, kidney and muscle samples were later freeze-dried and weighed again (dry weight, dw). Freeze-dried tissues were then ground and stored in individual plastic vials until further trace element and isotopic analyses. Breast feathers were washed to remove oil and dirt in a chloroform-methanol solution $(2: 1)$ in an ultrasonic bath for two minutes. Afterwards, they were rinsed in two consecutive pure methanol baths for a few seconds and dried at $40{ }^{\circ} \mathrm{C}$ for 48 hours prior to being used for trace element and stable isotope analyses.

\subsection{Trace element determination}

Total $\mathrm{Hg}$ analyses were carried out in shorebirds by atomic absorption spectrophotometry with an Advanced Mercury Analyser (ALTEC AMA 254) on dried tissue aliquots (liver, kidney, pectoral muscle, breast feathers) ranging from 4 to $50 \mathrm{mg}( \pm 0.01 \mathrm{mg})$ depending on the $\mathrm{Hg}$ concentration in the tissue following the protocol described in Bustamante et al. (2006). Mercury analyses were run under a thorough quality controlled program that includes analysis of Certified Reference Material (CRM; lobster hepatopancreas TORT-2; National Research Council, Canada). Standard aliquots were treated and analysed according to the 
same conditions as the samples. The results were in good agreement with the certified values, with a mean recovery rate of $92 \%$. The detection limit was $5 \mathrm{ng} \mathrm{Hg} \mathrm{g}^{-1} \mathrm{dw}$.

$\mathrm{Ag}, \mathrm{As}, \mathrm{Cd}, \mathrm{Co}, \mathrm{Cr}, \mathrm{Cu}, \mathrm{Fe}, \mathrm{Mn}, \mathrm{Ni}, \mathrm{Pb}, \mathrm{Se}$ and $\mathrm{Zn}$ were analysed using a Varian VistaPro ICP-OES and a Thermo Fisher Scientific XSeries II ICP-MS in the liver, kidney, pectoral muscle and breast feathers. Aliquots of the biological samples (30-300 mg) were digested with $6 \mathrm{ml} 67-70 \% \mathrm{HNO}_{3}$ and $2 \mathrm{ml} \mathrm{34-37 \%} \mathrm{HCl}$ (Fisher Scientific, trace element grade quality), with the exception of feathers $\left(3 \mathrm{ml} \mathrm{HNO}_{3}\right.$ and $\left.1 \mathrm{ml} \mathrm{HCl}\right)$. Acidic digestion of the samples was carried out overnight at room temperature, then using a Milestone microwave (30 min with constantly increasing temperature up to $120^{\circ} \mathrm{C}$, then $15 \mathrm{~min}$ at this maximal temperature). Each sample was brought up to a volume of $50 \mathrm{ml}$ (or $25 \mathrm{ml}$ for feathers) with milli-Q quality water. Three control samples (two CRMs and one blank) treated and analysed the same way as the samples were included in each analytical batch. The CRMs were dogfish liver DOLT-4 (NRCC) and lobster hepatopancreas TORT-2 (NRCC). Quantification limits and mean recovery rates were, respectively, equal to $0.1 \mu \mathrm{g} \mathrm{L}^{-1}$ and $82 \%$ for $\mathrm{Ag}, 1 \mu \mathrm{g} \mathrm{L}^{-1}$ and 98\% for As, $0.1 \mu \mathrm{g} \mathrm{L}^{-1}$ and $94 \%$ for $\mathrm{Cd}, 0.1 \mu \mathrm{g} \mathrm{L}^{-1}$ and $99 \%$ for $\mathrm{Co}, 0.1 \mu \mathrm{g} \mathrm{L}^{-1}$ and $102 \%$ for $\mathrm{Cr}, 5 \mu \mathrm{g} \mathrm{L} \mathrm{L}^{-1}$ and $93 \%$ for $\mathrm{Cu}, 20 \mu \mathrm{g} \mathrm{L}^{-1}$ and $86 \%$ for Fe, $5 \mu \mathrm{g} \mathrm{L}^{-1}$ and $90 \%$ for $\mathrm{Mn}, 0.2 \mu \mathrm{g} \mathrm{L}^{-1}$ and $101 \%$ for $\mathrm{Ni}, 0.1 \mu \mathrm{g} \mathrm{L}^{-1}$ and $86 \%$ for $\mathrm{Pb}, 0.5 \mu \mathrm{g} \mathrm{L}^{-1}$ and $109 \%$ for $\mathrm{Se}$, and $20 \mu \mathrm{g} \mathrm{L}^{-1}$ and 98\% for $\mathrm{Zn}$. Trace element concentrations are expressed in $\mu \mathrm{g} \mathrm{g}^{-1} \mathrm{dw}$. Values below the quantification limit were taken into account in calculating of the means by assigning them values one-half of the detection limit for the given element (e.g. a value $<0.02$ was reported as $\left.0.01 \mu \mathrm{g} \mathrm{g}^{-1} \mathrm{dw}\right)$.

\subsection{Nitrogen and carbon stable isotope analysis}

Stable isotopes were determined on the liver, muscle and breast feathers of birds. Cleaned feathers of shorebirds were chopped using surgical scissors and accurately weighed $( \pm 0.001$ $\mathrm{mg}$ ) to a range between 0.2 and $0.5 \mathrm{mg}$. Liver and muscle samples were also weighed with the same accuracy and in the same range of masses. All samples were placed in tin capsules for carbon and nitrogen stable isotope analysis and analysed using an elemental analyser (Flash EA 1112 fitted with a "No Blank" option, Thermo Scientific, Milan, Italy) coupled to an isotope ratio mass spectrometer (Delta V Advantage, Conflo IV interface, Smart EA option, Thermo Scientific, Bremen, Germany). The results are reported in $\delta$ unit notation (expressed in per mil relative to standards: Vienna Pee Dee Belemnite for $\delta^{13} \mathrm{C}$ and $\mathrm{N}_{2}$ in air for $\delta^{15} \mathrm{~N}$ ). 
The analytical precision of the measurements was $<0.06 \%$ and $<0.1 \%$ for carbon and nitrogen, respectively.

\subsection{Statistical analysis}

As normality and homogeneity of variance were not achieved despite $\log _{10}(x+1)$ transformation (Cochran $\mathrm{C}$ test), non-parametric analysis of variance (Kruskal-Wallis and Mann-Whitney U-test) was applied to assess differences in trace element concentrations between species, tissues, sexes or age classes using the software Statistica 7.1. Nonparametric analyses of variance (Kruskal-Wallis test) were also employed to study differences in stable isotopes values between species. Moreover, the Spearman test was applied to all correlations achieved in this study.

Principal Component Analysis (PCA) was used to identify trends in the distribution of trace element concentrations among individuals collected. $\mathrm{Ag}, \mathrm{As}, \mathrm{Cd}, \mathrm{Cu}, \mathrm{Fe}, \mathrm{Hg}, \mathrm{Mn}, \mathrm{Se}$ and $\mathrm{Zn}$ concentrations were used as variables for each analysis. $\mathrm{Co}, \mathrm{Cr}, \mathrm{Ni}$ and $\mathrm{Pb}$ concentrations were excluded of the analyses in reason of their low levels. Each trace element concentration was first normalized (mean was subtracted and the difference was then divided by standard deviation). Four separate analyses were performed on (1) liver, (2) kidneys, (3) muscle and (4) feathers data. These analyses were performed using the PERMANOVA + package (Anderson et al., 2008) from PRIMER v6 (Clarke and Gorley, 2006).

\section{Results}

\subsection{Trace element bioaccumulation in tissues}

The mean concentrations and ranges of the 13 trace elements in the liver, kidney, muscle and breast feathers of the dunlins and redshanks are presented in Tables 1 and 2 for nonessential and essential elements, respectively. Generally, non-essential trace element concentrations were low, especially for $\mathrm{Ag}$ and $\mathrm{Pb}$. Among tissues, the highest $\mathrm{Ag}$ concentrations were found in the liver of redshanks (Table 1). Concentrations of $\mathrm{Cd}$ were significantly higher in the kidney and liver of both species than in the other tissues (KruskalWallis test, all $\mathrm{p}<0.05$ ). It should be noticed that the elevated Cd concentrations in these tissues showed important variations between individuals in redshanks (Table 1). Indeed, five individuals out of the 15 sampled ones reached concentrations equal or above $3 \mu \mathrm{g} \mathrm{g}^{-1} \mathrm{dw}$ in their liver, and seven birds were also above this level in the kidney. Furthermore, Cd 
concentrations were positively correlated between all the tissues for dunlins and all the internal tissues only (liver, kidney, muscle) for redshanks (Spearman correlation test, all p < 0.05). Concentrations of $\mathrm{Hg}$ were the lowest in the muscle of both species, whereas liver and feathers highly accumulated this element. Positive correlations were observed between $\mathrm{Hg}$ concentrations of all the tissues for dunlins (Spearman correlation test, all $\mathrm{p}<0.05$ ). In contrast, concentrations of this element were only significantly linked between the liver and kidney $(\mathrm{R}=0.79)$ and the kidney and muscle $(\mathrm{R}=0.60)$ for redshanks.

In the case of essential trace elements, $\mathrm{Co}, \mathrm{Cr}$ and $\mathrm{Ni}$ concentrations were relatively low in the four tissues and for both species. Arsenic concentrations were significantly higher in the liver and kidney especially compared to feathers (Table 2). In dunlins, As concentrations of the liver, kidney and muscle were positively correlated to each other. In contrast, As concentrations of redshanks were only correlated between the liver and muscle. For this element, $43 \%$ of the dunlins and $53 \%$ of the redshanks exceeded concentrations of $5 \mu \mathrm{g} \mathrm{g}^{-1}$ $\mathrm{dw}$ in the liver. Iron and Se were also mainly bioaccumulated in the liver and kidney of both species. Nevertheless, Se concentrations of all tissues were positively correlated for both species (Spearman correlation test, all $\mathrm{p}<0.05$ ). The Se:Hg molar ratios were calculated in liver and kidney of redshanks and dunlins. The ratios always exceeded 1 for all the birds and ranged between 2.6 and 56.6 in the liver, and 2.5 and 93.1 in the kidney. Concentrations of $\mathrm{Fe}$ were only correlated between internal tissues (liver, kidney, muscle). Manganese was principally bioaccumulated in the feathers, especially for dunlins. Nevertheless, Mn concentrations of feathers were not correlated with other tissues studied. No significant differences appeared for $\mathrm{Cu}$, with the exception of the highest concentrations observed in the muscle of dunlins. Conversely, $\mathrm{Zn}$ concentrations were different between all the tissues studied, especially for dunlins.

\subsection{Comparison of trace element bioaccumulation between species}

Figure 2 presents a principal component analysis which was performed on the liver, kidney, muscle and feathers data to identify trends in the distribution of trace elements using dunlins and redshanks but also red knots and black-tailed godwits from the Pertuis Charentais. In reason of their low concentrations with many data below the detection limit of the analytical technique, $\mathrm{Co}, \mathrm{Cr}, \mathrm{Ni}$ and $\mathrm{Pb}$ were excluded from the analysis. The first two axes extracted $55.8,52.1,52.9$, and $43.4 \%$ of the variance of the data clouds in the liver, kidneys, muscle and feathers, respectively. In the liver, red knots were characterized by important As 
and Se concentrations, whereas black-tailed godwits were characterized by elevated $\mathrm{Ag}, \mathrm{Cu}$, $\mathrm{Fe}, \mathrm{Hg}, \mathrm{Mn}$ and $\mathrm{Zn}$ concentrations (Fig. 2A). Some of the redshanks displayed higher $\mathrm{Cd}$ concentrations. In contrast, dunlins were not characterized by any particular element. Generally, the same trends can be observed in the kidney for each species. A majority of red knots were still characterized by important Se concentrations and black-tailed godwits by elevated $\mathrm{Ag}, \mathrm{Cu}, \mathrm{Fe}, \mathrm{Hg}$ and $\mathrm{Zn}$ concentrations. Nevertheless, some individuals of this species were also discriminated by elevated $\mathrm{Cd}$ concentrations in this tissue. The main difference came from dunlins which appeared to be discriminated by their high As concentrations. This trend was also found in the muscle (Fig 2C) and corroborated by the elevated As and Se concentrations observed in dunlins and red knots (Table 2; Lucia et al., 2012b). In the muscle, godwits were discriminated by important $\mathrm{Cu}, \mathrm{Fe}, \mathrm{Hg}$ and $\mathrm{Zn}$ concentrations. Finally, dunlins were also characterized by higher As and Se concentrations in feathers while no significant trends can be observed for the other species in this tissue.

\subsection{Influence of sex, age and body weight on trace element bioaccumulation of the Dunlin and Redshank}

No trace element bioaccumulation differences could be tested between sites for the species because of the low number of individuals from Ré Island, Aiguillon and Yves bays. Indeed, the great majority of the birds were sampled at Marennes-Oléron Bay and the location was therefore not taken into account for further comparisons.

The sex of 27 dunlins (females: $\mathrm{n}=10$, males: $\mathrm{n}=17$ ) and 14 redshanks (females: $\mathrm{n}=8$, males: $\mathrm{n}=6$ ) was successfully determined during dissections. For dunlins, only few discrepancies were observed between males and females for most of the considered trace elements. Nevertheless, females displayed significantly higher Se concentrations than males in the kidney $\left(15.1 \pm 3.1\right.$ vs $10.3 \pm 4.8 \mu \mathrm{g} \mathrm{g}^{-1} \mathrm{dw}$, respectively; Mann-Whitney U-test, $\mathrm{p}=$ $0.014)$ and muscle $\left(8.4 \pm 2.4\right.$ vs $6.1 \pm 3.4 \mu \mathrm{g} \mathrm{g}^{-1} \mathrm{dw}$, respectively; $\left.\mathrm{p}=0.045\right)$. Females also had higher As concentrations in the muscle than males $\left(4.9 \pm 2.2\right.$ vs $3.2 \pm 1.9 \mu \mathrm{g} \mathrm{g}^{-1} \mathrm{dw}$, respectively; Mann-Whitney U-test, $\mathrm{p}=0.035)$. On the contrary, males displayed significantly higher $\mathrm{Cu}$ concentrations than females in feathers $\left(16.9 \pm 2.6\right.$ vs $14.8 \pm 2.4 \mu \mathrm{g} \mathrm{g}^{-1} \mathrm{dw}$, respectively; $\mathrm{p}=0.045)$.

For redshanks, females had significantly higher trace element concentrations than males for As $\left(7.4 \pm 3.2\right.$ vs $3.8 \pm 2.4 \mu \mathrm{g} \mathrm{g}^{-1} \mathrm{dw}$, respectively; $\left.\mathrm{p}=0.039\right)$ and $\mathrm{Se}(14.7 \pm 5.8$ vs $8.4 \pm$ $1.9 \mu \mathrm{g} \mathrm{g}^{-1} \mathrm{dw}$, respectively; $\left.\mathrm{p}=0.028\right)$ in the liver, for Mn $\left(7.8 \pm 2.0 v s 5.9 \pm 0.7 \mu \mathrm{g} \mathrm{g}^{-1} \mathrm{dw}\right.$, 
respectively; $\mathrm{p}=0.020)$ in the kidney, and for $\mathrm{Hg}\left(3.0 \pm 1.3 v s 1.4 \pm 0.7 \mu \mathrm{g} \mathrm{g}^{-1} \mathrm{dw}\right.$, respectively; $\mathrm{p}=0.020$ ) in the feathers.

Birds were categorized in two age classes (juveniles and adults). With only two juveniles redshanks sampled, the comparison between age-classes was not carried out for this species. Dunlins, however, demonstrated differences in elemental bioaccumulation between juveniles and adults. $\mathrm{Cu}$ concentrations were indeed significantly higher in juveniles than adults in the liver $\left(18.8 \pm 3.8 v \mathrm{~s} 15.8 \pm 1.7 \mu \mathrm{g} \mathrm{g}^{-1} \mathrm{dw}\right.$, respectively; Mann-Whitney U-test, $\left.\mathrm{p}=0.015\right)$ and kidneys $\left(16.4 \pm 2.2\right.$ vs $14.1 \pm 1.9 \mu \mathrm{g} \mathrm{g}^{-1} \mathrm{dw}$, respectively; $\left.\mathrm{p}=0.010\right)$.

The relation between trace element concentrations and the total body weight of the birds were investigated for the Red Knot and Redshank. For the first species, significant negative correlations appeared between the body weight of the birds and the $\mathrm{Cu}$ concentration in the liver $(\mathrm{R}=-0.46$; Spearman correlation test, $\mathrm{p}<0.05)$ and feathers $(\mathrm{R}=-0.59)$, as well as $\mathrm{Zn}$ concentration in the muscle $(\mathrm{R}=-0.53)$. In contrast, $\mathrm{Cd}$ concentrations in the muscle significantly increased with the body weight of the birds $(\mathrm{R}=0.42)$, alongside As concentrations in feathers $(\mathrm{R}=0.53)$. For the Redshank, Fe concentration was negatively correlated to the body weight of the birds in the liver $(\mathrm{R}=-0.62)$ and muscle $(\mathrm{R}=-0.65) . \mathrm{Cu}$, $\mathrm{Ni}$, and $\mathrm{Zn}$ concentrations in the muscle were also negatively linked to the body weight of redshanks $(\mathrm{R}=-0.68, \mathrm{R}=-0.60$, and $\mathrm{R}=-0.63$, respectively).

\subsection{Relationship between trophic position, feeding habitat and trace element} bioaccumulation

Trophic positions and foraging habitats, assessed respectively through the determination of $\delta^{15} \mathrm{~N}$ and $\delta^{13} \mathrm{C}$, of the four shorebird species were investigated in the liver, muscle and feathers (Fig. 3). In general, in the three tissues studied, the Redshank presented noticeably more positive values $\delta^{15} \mathrm{~N}$ than the other species. In the liver, the Red Knot showed significantly a less positive $\delta^{15} \mathrm{~N}$ value than the Dunlin and a less negative $\delta^{13} \mathrm{C}$ value than all the other species studied (Kruskal-Wallis test, $\mathrm{p}<0.05$ ). This trend is also observed in the muscle for $\delta^{13} \mathrm{C}$. Indeed, the Red Knot displayed a less negative carbon signature than the Black-tailed Godwit. In the feathers, the Godwit showed a more negative $\delta^{13} \mathrm{C}$ value than the Redshank.

All species confounded, $\delta^{15} \mathrm{~N}$ was positively correlated with $\mathrm{Hg}$ concentrations of the liver $(\mathrm{R}=0.37)$, muscle $(\mathrm{R}=028)$ and feathers $(\mathrm{R}=0.48$; Spearman test, $\mathrm{p}<0.05)$. The species with the highest $\mathrm{Hg}$ concentrations displayed also more positive $\delta^{15} \mathrm{~N}$ values (Fig. 4). Indeed, 
the Redshank which displayed the highest $\mathrm{Hg}$ concentrations in the three tissues also appeared to have more positive nitrogen isotopic signatures. In contrast the Red Knot had often lower $\mathrm{Hg}$ concentrations and $\delta^{15} \mathrm{~N}$ values than the other species, especially in the liver and muscle. The same trend was observed for As in the feathers $(R=0.35)$ and for Se in the muscle $(R=$ $0.53)$ and feathers $(\mathrm{R}=0.34)$. These two last element were also positively linked with carbon isotopic signatures in the liver $(\mathrm{R}=0.28$ and 0.24$)$ and the muscle $(\mathrm{R}=0.30$ and 0.29$)$ and the feathers $(\mathrm{R}=0.54$ and 0.40$)$ for As and $\mathrm{Se}$, respectively. In contrast, $\mathrm{Hg}$ concentrations were negatively correlated with $\delta^{13} \mathrm{C}$ values in the liver $(\mathrm{R}=-0.24)$.

\subsection{Influence of age-class and sampling season on trophic position and feeding habitat}

The influence of age-class on isotopic signatures was investigated for all species. For most of the age-class comparisons, no isotopic signature differences appeared, especially for redshanks and red knots. Nevertheless, adult of dunlins displayed higher $\delta^{13} \mathrm{C}$ values than juveniles in the feathers (Mann-Whitney U-test, $\mathrm{p}=0.003$ ). For black-tailed godwits, $\delta^{13} \mathrm{C}$ values of adults were significantly lower than juveniles $(\mathrm{p}=0.049)$.

Sampling seasons were determined according to the biological status of shorebirds. Consequently, autumn was considered beginning in late July and finishing at the end of October. This period includes the presence of shorebirds migrating to Africa and wintering in Europe. Winter was considered to be comprised between the beginning of November and the end of March (wintering season), while spring included April and May. Summer was therefore constituted by the rest of the year. Nevertheless, only three redshanks were sampled in this season. With the exception of this species, differences appeared depending on the season where birds were sampled in the Pertuis Charentais (Fig. 5). Indeed, the trophic position of dunlins sampled in winter was significantly higher than that of birds sampled in autumn for the muscle $(p=0.003)$ and the feathers $(p=0.034)$. The same trend was observed in the feathers of red knots $(\mathrm{p}=0.016)$ and in the muscle of black-tailed godwits $(\mathrm{p}=0.021)$. No significant differences were observed in regard of the foraging habitat of individuals $\left(\delta^{13} \mathrm{C}\right)$.

\section{Discussion}

This study allowed investigating and comparing the relation between trophic habits of several shorebird species and their trace element bioaccumulation. Previous studies mainly 
focused on a single species and used stable isotopes to explain variability in element concentrations within these species (Bearhop et al., 2000; Nisbet et al., 2002). Furthermore, because of the difficulty to obtain internal tissues of birds, other isotopic studies mainly used blood, eggs or external tissues such as feathers (Braune et al., 2002; Ofukany et al., 2012). This study provides therefore, for the first time, the opportunity to compare the link between elemental concentrations and feeding habits using various types of tissues at the community level.

\subsection{Trace element bioaccumulation in shorebird species}

In the environment, birds mainly accumulate trace elements through the food ingested even if some minor pathways exist such as atmospheric deposition and drinking water (Cosson et al., 1988). The current study, one the first characterising trace element accumulation of several shorebird species in relation to their feeding habits, demonstrated generally low elemental concentrations. It allowed however to differentiate the degree of bioaccumulation of species using potentially the same habitats: intertidal mudflats. First, red knots and dunlins were characterized by higher As concentrations in kidney but also in the liver for red knots, as previously pointed out by Lucia et al. (2012b). Depending on the chemical form ingested, this essential element could trigger several adverse effects in birds (Eisler, 1994; Kunito et al., 2008). Shorebirds of this study feed mainly on benthic macroinvertebrates (Mouritsen, 1994; Quaintenne et al., 2010; Robin et al., in press) which can accumulate inorganic forms of As (Dierschke et al., 1999). Moreover, even if As is mostly accumulated in its organic form, many organic arsenicals undergo biotransformation and organisms could be exposed to toxic intermediates (Albert et al. 2008).

Elevated Se concentrations also discriminated both species from redshanks and godwits, with however, red knots reaching twice the Se concentrations of dunlins in the liver and kidney (Lucia et al., 2012b). At high exposures, Se and $\mathrm{Hg}$ can each be individually toxic, but evidence supports that their co-accumulation reduces each other's toxic effects (Peterson et al., 2009). A Se:Hg molar ratio approaching 1 strongly suggest the existence of mercuric selenide (HgSe). In this study, ratios calculated in the liver and kidney of shorebirds always exceeded 1. Presumably, birds are protected against $\mathrm{Hg}$ toxicity but this result raises concern about the surplus of Se and its possible toxicity. Hepatic Se concentrations exceeding $10 \mu \mathrm{g} \mathrm{g}^{-}$

${ }^{1} \mathrm{dw}$ were associated with lower reproductive success in breeding female mallards (Heinz et al., 1987; Outridge et al., 1999; Stanley et al., 1996). It is remarkable that this element was 
highly accumulated in female dunlins and redshanks compared to males, as previously observed in American avocets Recurvirostra americana from the San Francisco Bay (Ackerman and Eagles-Smith, 2009). It is however difficult to explain differences between sexes since the feeding ecology of these species is not well known in all their stopovers. To our knowledge, no difference in the diet between sexes has been reported but it is likely that a difference exists in the amount females and males ingurgitate. Secondly, godwits were characterized by the highest $\mathrm{Ag}, \mathrm{Cu}, \mathrm{Fe}, \mathrm{Hg}, \mathrm{Mn}$ and $\mathrm{Zn}$ concentrations among the four species. This species appeared to accumulate a variety of elements probably through its diet which is mainly constituted by the bivalves Macoma balthica and Scrobicularidae in the Pertuis Charentais (Robin et al., in press). Finally, redshanks were characterized by the highest $\mathrm{Cd}$ concentrations in the liver and kidney compared to the other species. This bioaccumulation could come from a variety of sites where they forage during their migration route, but nevertheless the Pertuis Charentais are known to be contaminated by this element through the Gironde and Charente estuaries discharges (Boutier et al., 2000; Jouanneau et al., 1990; Pigeot et al., 2006).

All these discrepancies in element bioaccumulation could mainly come from the repartition of the trophic resources between the shorebirds on a same site and the variety of sites and prey they use along their migratory pathways. Dunlins and redshanks are considered are generalist species and feed in diverse habitats on a larger range of prey species (Dierschke et al., 1999; Goss-Custard and Jones, 1976, Goss-Custard et al., 1997; Lifjeld, 1983; Vieillard, 1973; Yasué et al., 2003) than red knots and black-tailed godwits which are more specialized and dependent of intertidal mudflat habitats in winter (Piersma, 2007). In intertidal coastal habitats, dunlins mainly feed on marine polychaetes, molluscs and crustaceans (Davidson, 1971; Durell and Kelly, 1990; Mouritsen, 1994; Worrall, 1984), while various molluscs, crustaceans, oligochaetes and insect larvae have been found in the food of dunlins migrating through inland Europe (Sterbetz, 1992). In various sites, dunlins are indeed able to switch their diet to juvenile fish, shrimps, and dipteran larvae or spilled amphipods as observed in the southern Baltic Sea (Dierschke et al., 1999). This species is able to meet its daily energy requirements in a variety of coastal and freshwater habitats because, compared to most of shorebird species, they display greater flexibility in foraging modes in response to environmental changes (Baker and Baker, 1973). In Europe, the Redshank diet demonstrated also a high variety of prey on intertidal mudflat (Goss-Custard and Jones, 1976; Goss-Custard et al., 1997) but they can seasonally shift on others feeding habitats like marshes or saltworks (Masero and Pérez-Hutardo, 2001; Sánchez et al., 2005). In contrast, red knots feed almost 
exclusively on marine molluscs (Piersma et al., 1993) such as M. balthica, Cerastoderma edule and Hydrobia ulvae (Quaintenne et al., 2010). In some sites such as Marennes-Oléron, up to $87 \%$ of the food ingested was constituted by H. ulvae (Quaintenne et al., 2010). Unfortunately, any clear conclusion could be drawn about the origins of the trace element bioaccumulation of each species because of the lack of specific data on element concentrations of macrofaunal community in all the sites birds cross. It is however apparent that one tissue is not sufficient enough to drawn conclusion about trace element bioaccumulation variations between species, especially when studying shorebirds species with a multiplicity of origins. Concentrations typically differ among tissues according to mechanisms specific to molecular binding and metabolic rate (Boudou and Ribeyre, 1995; Muir et al., 1988). Indeed, results demonstrated that trends observed in internal tissues such as liver and kidney were not necessarily observed in feathers. In this tissue, dunlins were characterized by elevated As and Se concentrations but no clear patterns could be noticed for the other species. Feathers are indeed a record of exposure during the months preceding their growth, especially for $\mathrm{Hg}$. Once the feather is formed, the blood irrigation subsides implying that no further trace element can be deposited. Moulting process represents therefore an excretory outlet for trace elements such as $\mathrm{Hg}$ (Thompson and Furness, 1989). In contrast, the liver and kidney are tissues involved in detoxification processes. Consequently, these organs store high levels of non-essential elements such as $\mathrm{Cd}$ in vertebrate top predators, as observed in this study (Arai et al., 2004; Stewart et al., 1996).

\subsection{Relationship between trophic position, feeding habitat and trace element bioaccumulation}

In this study, important variations of isotopic signatures were found in regards of the sampling season, especially for the Dunlin and the Red Knot. This result could be mainly explained by the multiplicity of subspecies and populations with different phenologies and different length of stay on the local intertidal mudflats. For example, two subspecies of godwits could be recorded in the study area with $L$. l. islandica wintering from September to March and L. l. limosa only present during fall and spring migrations (Robin, 2011). Nevertheless, the great majority of the birds sampled belonged to the wintering subspecies $L$. l. islandica and their isotopic signatures in the liver attest of their local diet while the values for staging birds in migration probably partly attest of their diet in the previous stopover or wintering site. The same pattern is encountered for the three others species along the East 
Atlantic Flyway with two, three and four subspecies for Red Knot, Dunlin and Redshank, respectively. For each species at least one population winters in Africa and can be found in the Pertuis in autumn or in spring (Cramp and Simmons, 1983; Delany et al., 2009).

In the present study, the trophic position of redshanks and dunlins appeared noticeably higher than in red knots and black-tailed godwits in the three tissues studied. As described previously, both species are considered as generalist species with a larger range of prey species in diverse habitats such as insect larvae, amphipods or crustaceans (Dierschke et al., 1999). In complement, red knots seem to use different niches than the other species with more marine carbon signatures enriched in ${ }^{13} \mathrm{C}$ in internal tissues, especially in the liver. Nevertheless, the same trend was not observed for feathers where differences were observed between dunlins, red knots and black-tailed godwits. This result clearly demonstrates variations occurring between tissues.

Stable isotope analysis has become a powerful tool to study dietary exposure and biomagnification of contaminants in wild animal populations. In this study, nitrogen signatures of birds were positively related to $\mathrm{Hg}$ concentrations meaning that the more birds fed on prey enriched in ${ }^{15} \mathrm{~N}$, the more their $\mathrm{Hg}$ concentrations were elevated. $\mathrm{Hg}$ under its methylated form is well known for its ability to biomagnify in aquatic food webs (Kidd et al., 1995; Kwon et al., 2012; Polak-Juszczak, 2012). This biomagnification trend was verified with shorebirds of the Pertuis Charentais (Fig. 4). Redshanks had higher trophic status and also higher $\mathrm{Hg}$ concentrations in the three tissues, especially feathers, than the other three species. First, this result demonstrates that compared to other species, redshanks consume prey with higher $\mathrm{Hg}$ concentrations. In contrast, the long-migrant red knots had lower $\mathrm{Hg}$ concentrations and $\delta^{15} \mathrm{~N}$ values than the other species. Overall, it appears that the bird species with the ability to feed on a variety of prey in different coastal ecosystems displayed greater $\mathrm{Hg}$ concentrations than more specialized ones. Previous authors have observed this pattern for inland wading birds in the southeastern United-States (Bryan et al., 2012). However, the same authors observed that differential use of freshwater and saltwater aquatic systems in coastal environments by wading bird species leads to variations in $\delta^{15} \mathrm{~N}$ values and $\mathrm{Hg}$ contents in nestling feathers which also result in the opposite trend expected for $\mathrm{Hg}$ biomagnification in food chains. It clearly contrasts with the present study where generalist species such as redshanks able to feed on a variety of habitats displayed elevated $\mathrm{Hg}$ concentrations and $\delta^{15} \mathrm{~N}$ values. Importantly, beside this inter-specific effect of feeding habitat and diet, the correlations found between $\mathrm{Hg}$ concentrations and $\delta^{15} \mathrm{~N}$ values in all the tissues demonstrates that feathers could act as a good indicator for $\mathrm{Hg}$ bioamplification in shorebird species. 
Biomagnification of Se has been reported by some authors (Lemly, 1985, 1999; Muscatello and Janz, 2009) and argued by others (Barceloux, 1999; Saiki et al., 1993). In the present study, Se biomagnification was observed in muscle and feathers of shorebirds from the Pertuis Charentais, as revealed by the positive correlation between $\delta^{15} \mathrm{~N}$ values and $\mathrm{Se}$ concentrations in both tissues. The more birds fed on high trophic status prey, the more they presented elevated Se concentrations in their tissues. This result was especially observed in the feathers for which dunlins and redshanks displayed the highest Se concentrations and $\delta^{15} \mathrm{~N}$ values compared to the other species. Nevertheless, this pattern was not observed in the liver. This result suggests that biomagnification process happened during the growth of feathers.

Biomagnification has also been shown for As in aquatic systems (Suedel et al., 1994). In the present study, this trend was only found in the feathers but not in the internal tissues. Interestingly, both As and Se were positively linked to carbon ratios in birds. This result demonstrate that birds feeding in more marine habitats are more exposed to As and Se. One of the principal outcomes of this study is the differences appearing between tissues when investigating the link between trace elements and feeding ecology of shorebirds. As stated above, different tissues represent different period of dietary integrations of such elements as well as different tendency to accumulate specific elements (Hobson et al., 2004). Tissues from animals that periodically switch diets in response to changes in prey availability or habitat may have distinctive isotopic ratios depending on the turnover rate of the tissue, the isotopic composition of the new diet, and the duration of the diet switch (Jardine et al., 2006). Overall, these results suggest that feathers are an important tissue to analyse in terms of long-term exposure of birds to trace elements such as $\mathrm{As}, \mathrm{Hg}$, and Se resulting from past dietary habits.

This study demonstrated that shorebirds using the same habitats in the Pertuis Charentais were characterized by differential trace element bioaccumulation. Concentrations of As and Se tend to be elevated in red knots and dunlins and possibly could trigger adverse effects in these species (Heinz et al., 1987; Kunito et al., 2008; Outridge et al., 1999; Stanley et al., 1996). Redshanks displayed however higher $\mathrm{Cd}$ concentrations in internal tissues. These patterns in element bioaccumulation could mainly come from the divergence of trophic habits between shorebirds. For some elements such as $\mathrm{Hg}$, trophic positions of shorebirds mainly explain variations in bioaccumulation. This study also demonstrated the biomagnification potential of this metal (Polak-Juszczak, 2012). Nevertheless, these data highlighted the need to study several tissues to obtain a full comprehension of trace element exposure and pathways in species using various habitats during their migration and reproduction period. 
Indeed, feathers could act as a good bioindicator for elements such as $\mathrm{Hg}$ and $\mathrm{Se}$, but may not represent internal bioaccumulation for others.

In reason of their migratory status, shorebirds are led to regularly change their diets and habitats along their distribution area (Dierschke et al., 1999; Masero and Pérez Hutardo, 2001). Our results demonstrate the complexity to link trace element concentrations to trophic positions and diets of shorebirds able to regularly change their feeding habitat during their annual cycle through a large range of latitudes. The multiplicity of subspecies and populations for each species with different origins but overlapping temporally on the same ecosystems makes even more complex to identify trends between the element bioaccumulations and the feeding ecology of shorebirds. It appears necessary when working on migrating birds to distinguish as much as possible the origins of individuals in order to clearly dissociate the different subspecies and populations for comparison inside communities.

Acknowledgements The authors wish to thank the University of La Rochelle for its financial support through a post-doctoral grant to ML, as well as the Natural Reserves of the Pertuis Charentais (Moëze-Oléron, Marais d'Yves, Lilleau des Niges, Baie de l'Aiguillon) for their technical assistance during bird catches. We especially thank P. Rousseau, J. Gautier and J. Gonin, N. Boileau, F. Corre, L. Jomat, S. Guenneteau, V. Lelong from the Moëze-Oléron Natural Reserve. We also thank P. Richard and G. Guillou (UMR LIENSs) for technical support during stable isotope analysis. This work was supported financially by the CPER (Contrat de Projet Etat-Région) and the CNRS.

\section{References}

Ackerman, J.T., Eagles-Smith, C.A., 2009. Selenium bioaccumulation and body condition in shorebirds and terns breeding in San Francisco Bay, California, USA. Environ. Toxicol. Chem. 28, 2134-2141.

Albert, C.A., Williams, T.D., Morrissey, C.A., Lai, V.W.M., Cullen, W.R., Elliott, J.E., 2008. Dose-dependent uptake, elimination, and toxicity of monosodium methanearsonate in adult zebra finches (Taeniopygia guttata). Environ. Toxicol. Chem. 27, 605-611.

Anderson, M.J., Gorley, R.N., Clarke, K.R., 2008. PERMANOVA + for PRIMER: Guide to software and statistical methods. PRIMER-E Ltd, Plymouth.

Arai, T., Ikemoto, T., Hokura, A., Terada, Y., Kunito, T., Tanabe, S., Nakai, I., 2004. Chemical forms of mercury and cadmium accumulated in marine mammals and seabirds as determined by XAFS analysis. Environ. Sci. Technol. 15, 6468-6474. 
Baker, M.C., Baker, A.E.M., 1973. Niche relationships among six species of shorebirds on their wintering and breeding ranges. Ecol. Monogr. 43, 193-212.

Barceloux DG., 1999. Selenium. Clin. Toxicol. 37, 145-172.

Bearhop, S., Waldron, S., Thompson, D., Furness, R., 2000. Bioamplification of mercury in great skua Catharacta skua chicks: the influence of trophic status as determined by stable isotope signatures of blood and feathers. Mar. Pollut. Bull. 40, 181-185.

Boudou, A., Ribeyre, F., 1995. Mercury in the foodweb: accumulations and transfer mechanisms, in: Sigel, A.A., Sigel, H. (eds), Metal ions in biological systems. Marcel Dekker Inc, New York, pp. 289-319.

Boutier, B., Chiffoleau, J.F., Gonzalez, J.L., Lazure, P., Auger, D., Truquet, I., 2000. Influence of the Gironde estuary outputs on cadmium concentrations in the waters: consequences on the Marennes-Oléron bay (France). Oceanol. Acta 23, 745-757.

Braune, B.M., Donaldson, G.M., Hobson, K.A., 2002. Contaminant residues in seabird eggs from the Canadian Arctic. II. Spatial trends and evidence from stable isotopes for intercolony differences. Environ. Pollut. 117, 133-145.

Bryan, A.L. Jr, Brant, H.A., Jagoe, C.H., Romanek, C.S., Brisbin, I.L. Jr., 2012. Mercury concentrations in nestling wading birds relative to diet in the southeastern United States: a stable isotope analysis. Arch. Environ. Contam. Toxicol. 63, 144-152.

Burger, J., 1993. Metals in avian feathers: bioindicators of environmental pollution. Rev. Environ. Toxicol. 5, 203-311.

Bustamante, P., Lahaye, V., Durnez, C., Churlaud, C., Caurant, F., 2006. Total and organic $\mathrm{Hg}$ concentrations in cephalopods from the North Eastern Atlantic waters: influence of geographical origin and feeding ecology. Science of the Total Environment 368, 585-596.

Bustamante, P., Miramand, P., 2004. Interspecific and geographical variations of trace element concentrations in Pectinidae from European waters. Chemosphere 57, 13551362 .

Bustamante, P., Miramand, P., 2005. Subcellular and body distributions of 17 trace elements in the variegated scallop Chlamys varia from the Charente-Maritime coast (Bay of Biscay, France). Sci. Total Environ. 337, 59-79.

Campbell, L.M., Norstrom, R.J., Hobson, K.A., Muir, D.C.G., Backus, S., Fisk, A.T., 2005. Mercury and other trace elements in a pelagic Arctic marine food web (Northwater Polynya, Baffin Bay). Sci. Total Environ. 351-352, 247-263.

Clarke, K.R., Gorley, R.N., 2006. PRIMER v6: User manual/Tutorial. PRIMER-E Ltd, Plymouth. 
Cosson, R., Amiard-Triquet, C., Amiard, J.C., 1988. Utilisation des plumes dans la recherche des sources de contamination des oiseaux par les éléments traces: $\mathrm{Cd}, \mathrm{Cu}, \mathrm{Hg}, \mathrm{Pb}, \mathrm{Se}$, et Zn chez les flamants de Camargue, France. Water Air Soil Pollut. 42, 103-115.

Cramp, S., Simmons, K.E.L., 1983. The Birds of the Western Paleartic. Oxford University Press, Oxford.

Davidson, P.E., 1971. Some foods taken by waders in Morecambe Bay, Lancashire. Bird Study 18, 177-186.

Delany, S., Scott, D., 2006. Waterbird Population Estimates, fourth ed. Wetlands International, Wageningen.

Delany, S., Scott, D., Dobman, T., Stroud, D., 2009. An atlas of wader population in Africa and Western Eurasia. Wetlands International, Wageningen.

Dierschke, V., Kube, J., Probst, S., Brenning, U., 1999. Feeding ecology of dunlins Calidris alpina staging in the southern Baltic Sea, 1. Habitat use and food selection. J. Sea Res. $42,49-64$.

Durell, S.E.A. Le V. dit, Kelly, C.P., 1990. Diets of Dunlin Calidris alpina and Grey Plover Pluvialis squatarola on the Wash as determined by dropping analysis. Bird Study 37, 4447.

Eisler, R.A., 1994. A review of arsenic hazards to plants and animals with emphasis on fishery and wildlife resources, in: Nriagu, J.O. (ed), Arsenic in the Environment, Part II: Human Health and Ecosystem Effects. Wiley, New York, pp. 185-259.

Goss-Custard, J.D., Jones, R.E., 1976. The diets of Redshank and Curlew. Bird Study 23, 223-243.

Goss-Custard, J.D., Kay, D.G., Blindell, R.M., 1977. The density of migratory and overwintering Redshank, Tringa totanus (L.) and Curlew, Numenius aquarta (L.), in relation to the density of their prey in South-east England. Estuar. Coast. Mar. Sci. 5, 497-510.

Halpern, B.S., Walbridge, S., Selkoe, K.A., Kappel, C.V., Micheli, F., D’Agrosa, C., Bruno, J.F., Casey, K.S., Ebert, C., Fox, H.E., Fujita, R., Heinemann, D., Lenihan, H.S., Madin, E.M.P., Perry, M.T., Selig, E.R., Spalding, M., Steneck, R., Watson, R., 2008. A global map of human impact on marine ecosystems. Science 319, 948-952.

Heinz, G.H., Hoffman, D.J., Krynitsky, A.J., Weller, D.M.G., 1987. Reproduction of mallards fed selenium. Environ. Toxicol. Chem. 6, 423-433.

Hobson, K.A., Riget, F.F., Outridge, P.M., Dietz, R., Born, E., 2004. Baleen as a biomonitor of mercury content and dietary history of North Atlantic Minke Whales (Balaenopetra 
acutorostrata): combining elemental and stable isotope approaches. Sci. Total Environ. $331,69-82$.

Jardine, T.D., Kidd, K.A., Fisk, A.T., 2006. Applications, considerations, and sources of uncertainty when using stable isotope analysis in ecotoxicology. Environ. Sci. Technol. 40, 7501-7511.

Jarman, W.M., Hobson, K.A., Sydeman, W.J., Bacon, C.E., McLaren, E.B., 1996. Influence of trophic position and feeding location on contaminant levels in the Gulf of the Farallones food web revealed by stable isotope analysis. Environ. Sci. Technol. 30, 654660.

Jouanneau, J.M., Boutier, B., Chiffoleau, J.F., Latouche, C., Philipps, I., 1990. Cadmium in the Gironde fluvioestuarine system: behaviour and flow. Sci. Total Environ. 97/98, 465479.

Kidd, K.A., Hesslein, R.H., Fudge, R.J., Hallard, K.A., 1995. The influence of trophic level as measured by $\delta^{15} \mathrm{~N}$ on mercury concentrations in freshwater organisms. Water Air Soil Pollut. 80, 1011-1015.

Kunito, T., Kubota, R., Fujihara, J., Agusa, T., Tanabe, S., 2008. Arsenic in marine mammals, seabirds, and sea turtles. Rev. Environ. Contam. Toxicol. 195, 31-69.

Kwon, S.Y., McIntyre, P.B., Flecker, A.S., Campbell, L.M., 2012. Mercury biomagnification in the food web of a neotropical stream. Sci. Total Environ. 417-418, 92-97.

Lemly, A., 1985. Toxicology of selenium in a freshwater reservoir: implications for environmental hazard evaluations and safety. Ecotoxicol. Environ. Saf. 34, 223-227.

Lemly, A., 1999. Selenium transport and bioaccumulation in aquatic systems: a proposal for water quality criteria based on hydrological units. Ecotoxicol. Environ. Saf. 42, 150-156.

Lifjeld, J., 1983. Stomach content analyses of the Dunlin Calidris alpina: bias due to differential digestibility of prey items. Cinclus 6, 43-46.

Lucia, M., Bocher, P., Cosson, R.P., Churlaud, C., Robin, F., Bustamante, P., 2012a. Insight on trace element detoxification in the Black-tailed Godwit (Limosa limosa) through genetic, enzymatic and metallothionein analyses. Sci. Total Environ. 423, 73-83.

Lucia, M., Bocher, P., Cosson, R.P., Churlaud, C., Bustamante, P., 2012b. Evidence of species-specific detoxification processes for trace elements in shorebirds. Ecotoxicology $21,2349-2362$.

Mahéo, R., 2011. Limicoles séjournant en France (Littoral), $34^{\text {ème }}$ contribution française aux dénombrements internationaux des oiseaux d'eau organisés par Wetlands International. Office national de la chasse et de la faune Sauvage, France. 
Masero, A., Pérez-Hutardo, A., 2001. Importance of the supratidal habitats for maintaining overwintering shorebird populations: How Redshanks use tidal mudflats and adjacent saltworks in southern Europe. The Condor 103, 21-30.

Mouritsen, K.N., 1994. Day and night feeding in Dunlins Calidris alpina: choice of habitat, foraging technique and prey. J. Avian Biol. 25, 55-62.

Muir, D.C.G., Wagemann, R., Grift, N., Norstrom, R.J., Simon, M., Lein, J., 1988. Organochlorine chemical and heavy metal contaminants in white-beaked dolphins (Lagenorhynchus albirostis) and pilot whales (Globicephala melaena) from the coast of Newfoundland Canada. Arch. Environ. Contam. Toxicol. 17, 613-629.

Muscatello, J.R., Janz, D.M., 2009. Selenium accumulation in aquatic biota downstream of a uranium mining and milling operation. Sci. Total Environ. 407, 1318-1325.

Nisbet, I.C.T., Montoya, J.P., Burger, J., Hatch, J.J., 2002. Use of stable isotopes to investigate individual differences in diets and mercury exposures among common terns Sterna hirundo in breeding and wintering grounds. Mar. Ecol. Prog. Ser. 242, 267-274.

Nriagu, J.O., 1996. A history of global metal pollution. Science 272, 223-224.

Ofukany, A.F.A., Hobson, K.A., Wassenaar, L.I., 2012. Connecting breeding and wintering habitats of migratory piscivorous birds: implications for tracking contaminants $(\mathrm{Hg})$ using multiple stable isotopes. Environ. Sci. Technol. 46, 3263-3272.

Outridge, P.M., Scheuhammer, A.M., Fox, G.A., Braune, B.M., White, L.M., Gregorich, L.J., 1999. An assessment of the potential hazards of environmental selenium for Canadian wildlife. Environ. Rev. 7, 81-96.

Peterson, S.A., Ralston, N.V.C., Peck, D.V., Van Sickle, J., Robertson, J.D., Spate, V.L., Morris, J.S., 2009. How might selenium moderate the toxic effects of mercury in stream fish of the Western U.S.? Environ. Sci. Technol. 43, 3919-3925.

Piersma, T., 2007. Using the power of comparison to explain habitat use and migration strategies of shorebirds worldwide. J. Ornithol. 148, S45-S59.

Piersma, T., Hoekstra, R., Dekinga, A., Koolhaas, A., Wolf, P., Battley, P., Wiersma, P., 1993. Scale and intensity of intertidal habitat use by knots Calidris canutus in the western Wadden Sea in relation to food, friends and foes. Neth. J. Sea Res. 31, 319-330.

Pigeot, J., Miramand, P., Guyot, T., Sauriau, P.G., Fichet, D., Le Moine, O., Huet, V., 2006. Cadmium pathways in an exploited intertidal ecosystem with chronic cadmium inputs (Marennes-Oléron, Atlantic coast, France). Mar. Ecol. Prog. Ser. 307, 101-114.

Polak-Juszczak, L., 2012. Bioaccumulation of mercury in the trophic chain of flatfish from the Baltic Sea. Chemosphere 89, 585-591. 
Quaintenne, G., van Gils, J.A., Bocher, P., Dekinga, A., Piersma, T., 2010. Diet selection in a molluscivore shorebird across Western Europe: does it show short- or long-term intake rate-maximization? J. Anim. Ecol. 79, 53-62.

Quinn, M.R., Feng, X., Folt, C.L., Chamberlain, C.P., 2003. Analyzing trophic transfer of metals in stream food webs using nitrogen isotopes. Sci. Total Environ. 317, 73-89.

Robin, F., 2011. Dynamique de la distribution, sélection de l'habitat et stratégie d'alimentation chez la barge à queue noire Limosa limosa à l'échelle des sites d'hivernage français. University of La Rochelle, France.

Robin, F., Piersma, T., Meunier, F., Bocher, P., 2013. Expansion into an herbivorous niche by a customary carnivore: Black-tailed godwits feeding on rhizomes of Zostera at a newly established wintering site. The Condor.

Saiki, M.K., Jennings, M.R., Brumbaugh, W.G., 1993. Boron, molybdenum, and selenium in aquatic food chains from the lower San Joaquin River and its tributaries, California. Arch. Environ. Contam. Toxicol. 24, 307-319.

Sánchez, M.I., Green, A.J., Castellanos, E.M., 2005. Seasonal variation in the diet of Redshank Tringa totanus in the Odiel Marshes, southwest Spain: a comparison of faecal and pellet analysis: Capsule Redshank diet from southern Europe during migration shows spatial and seasonal variations. Bird Study 52, 210-216.

Stanley, T.R. Jr., Smith, G.J., Hoffman, D.J., Heinz, G.H., Rosscoe, R., 1996. Effects of boron and selenium on mallard reproduction and duckling growth and survival. Environ. Toxicol. Chem. 15, 1124-1132.

Sterbetz, I., 1992. Foods of Dunlin (Calidris alpina) in Hungary. Aquila 99, 49-57.

Stewart, F.M., Furness, R.W., Monteiro, L.R., 1996. Relationships between heavy metal and metallothionein concentrations in lesser black-backed gulls, Larus fuscus, and Cory's shearwater, Calonectris diomedea. Arch. Environ. Contam. Toxicol. 30, 299-305.

Stroud, D.A., Baker, A., Blanco, D.E., Davidson, N.C., Delany, S., Ganter, B., Gill, R., González, P., Haanstra, L., Morrison, R.I.G., Piersma, T., Scott, D.A., Thorup, O., West, R., Wilson, J., Zöckler, C., 2006. The conservation and population status of the world's waders at the turn of the millennium, in: Boere, G.C., Galbraith, C.A., Stroud, D.A. (Eds.), Waterbirds around the world. The Stationery Office, Edinburgh, pp. 643-648.

Suedel, B.C., Boraczek, J.A., Peddicord, R.K., Clifford, P.A., Dillon, T.M., 1994. Trophic transfer and biomagnification potential of contaminants in aquatic ecosystems. Rev. Environ. Contam. Toxicol. 136, 21-89. 
Thompson, D.R., Furness, R.W., 1989. The chemical form of mercury stored in south Atlantic seabirds. Environ. Pollut. 60, 305-317.

Vielliard, J., 1973. Autoécologie comparée du Bécasseau variable. Alauda 41, 1-33.

Vitousek, P.M., Mooney, H.A., Lubchenco, J., Melillo, J.M., 1997. Human domination of earth's ecosystems. Science 277, 494-499.

Worrall, D.H., 1984. Diet of the Dunlin Calidris alpina in the Severn Estuary. Bird Study 31, 203-212.

Yasué, M., Quinn, J.L., Cresswell, W., 2003. Multiple effects of weather on the starvation and predation risk trade-off in choice of feeding location in Redshanks. Funct. Ecol. 17, 727736. 
Table 1. Concentrations (Mean $\pm \mathrm{SD}$, range; $\mu \mathrm{g} \mathrm{g}^{-1} \mathrm{dw}$ ) of non-essential trace elements in the tissues of the Dunlin Calidris alpina and the Redshank Tringa totanus from the Pertuis Charentais (Atlantic coast of France).

\begin{tabular}{|c|c|c|c|c|c|c|c|c|}
\hline Element & \multicolumn{4}{|c|}{ Dunlin ( $n=28)$} & \multicolumn{4}{|c|}{ Redshank (n=15) } \\
\hline $\mathrm{Ag}$ & $<0.03-0.10$ & $<0.02-0.05$ & $<0.02-0.09$ & $<0.02-0.16$ & $<0.02-1.70$ & $<0.03-0.23$ & $<0.02-0.02$ & $0.02-0.13$ \\
\hline $\mathrm{Cd}$ & $0.64 \pm 0.20^{\mathrm{a}}$ & $2.02 \pm 3.41^{\mathrm{a}}$ & $0.09 \pm 0.13^{b}$ & $0.03 \pm 0.02^{b}$ & $5.55 \pm 11.02^{\mathrm{a}}$ & $18.7 \pm 53.5^{a}$ & $0.65 \pm 2.13^{b}$ & $0.04 \pm 0.03^{b}$ \\
\hline \multirow[t]{2}{*}{$\mathrm{Hg}$} & $1.41 \pm 0.73^{\mathrm{a}}$ & $0.86 \pm 0.44^{b}$ & $0.40 \pm 0.22^{c}$ & $1.83 \pm 1.48^{\mathrm{a}}$ & $2.71 \pm 1.21^{\mathrm{a}}$ & $1.83 \pm 0.77^{\mathrm{a}}$ & $0.67 \pm 0.25^{b}$ & $2.18 \pm 1.35^{a}$ \\
\hline & $0.40-3.69$ & $0.25-2.26$ & $0.15-1.04$ & $0.25-7.45$ & $1.21-4.75$ & $0.78-3.71$ & $0.24-1.15$ & $0.56-4.58$ \\
\hline $\mathrm{Pb}$ & $0.13 \pm 0.08^{\mathrm{a}}$ & $0.40 \pm 0.34^{\mathrm{a}}$ & $0.02 \pm 0.02^{b}$ & $1.12 \pm 0.89^{c}$ & $0.11 \pm 0.06^{\mathrm{a}}$ & $0.29 \pm 0.33^{\mathrm{ac}}$ & $0.01 \pm 0.01^{b}$ & $0.88 \pm 0.43^{c}$ \\
\hline
\end{tabular}

Significant differences between tissues for each trace element and species distinctly are indicated by letters at the level $\alpha=0.05$ (Kruskal-Wallis test). 
Table 2. Concentrations (Mean $\pm \mathrm{SD}$, range; $\mu \mathrm{g} \mathrm{g}^{-1} \mathrm{dw}$ ) of essential trace elements in the tissues of the Dunlin Calidris alpina and the Redshank Tringa totanus from the Pertuis Charentais (Atlantic coast of France).

\begin{tabular}{|c|c|c|c|c|c|c|c|c|}
\hline \multirow[t]{2}{*}{ Element } & \multicolumn{4}{|c|}{ Dunlin $(n=28)$} & \multicolumn{4}{|c|}{ Redshank ( $n=15)$} \\
\hline & liver & kidney & muscle & feathers & liver & kidney & muscle & feathers \\
\hline \multirow[t]{2}{*}{ As } & $4.82 \pm 2.52^{\mathrm{a}}$ & $5.66 \pm 2.86^{\mathrm{a}}$ & $3.96 \pm 2.18^{\mathrm{ab}}$ & $2.46 \pm 2.24^{b}$ & $5.52 \pm 3.50^{\mathrm{a}}$ & $3.56 \pm 1.66^{\mathrm{a}}$ & $2.44 \pm 1.77^{\mathrm{ab}}$ & $0.77 \pm 0.67^{b}$ \\
\hline & $0.89-10.5$ & $1.12-12.24$ & $<0.18-8.16$ & $0.27-8.70$ & $0.51-11.5$ & $0.37-6.05$ & $<0.19-5.72$ & $<0.20-2.69$ \\
\hline \multirow[t]{2}{*}{ Co } & $0.22 \pm 0.11^{\mathrm{a}}$ & $0.28 \pm 0.15^{\mathrm{a}}$ & $0.07 \pm 0.03^{b}$ & $0.14 \pm 0.15^{b}$ & $0.11 \pm 0.04^{\mathrm{a}}$ & $0.23 \pm 0.06^{b}$ & $0.04 \pm 0.02^{c}$ & $0.08 \pm 0.04^{\mathrm{ac}}$ \\
\hline & $0.11-0.52$ & $0.13-0.68$ & $<0.02-0.14$ & $0.03-0.85$ & $0.07-0.21$ & $0.12-0.37$ & $<0.02-0.08$ & $0.02-0.15$ \\
\hline \multirow[t]{2}{*}{$\mathrm{Cr}$} & $0.85 \pm 2.93^{\mathrm{a}}$ & $0.36 \pm 0.42^{\mathrm{a}}$ & $0.55 \pm 1.18^{\mathrm{a}}$ & $0.31 \pm 0.35^{\mathrm{a}}$ & $0.16 \pm 0.17^{\mathrm{a}}$ & $0.47 \pm 0.69^{a b}$ & $0.10 \pm 0.11^{\mathrm{a}}$ & $0.39 \pm 0.37^{b}$ \\
\hline & $0.03-15.5$ & $<0.04-2.03$ & $<0.02-4.61$ & $<0.02-1.86$ & $0.03-0.69$ & $0.05-2.24$ & $<0.02-0.42$ & $0.10-1.62$ \\
\hline \multirow[t]{2}{*}{$\mathrm{Cu}$} & $17.2 \pm 3.2^{\mathrm{a}}$ & $15.2 \pm 2.3^{\mathrm{a}}$ & $23.7 \pm 2.9^{b}$ & $16.1 \pm 2.6^{\mathrm{a}}$ & $24.3 \pm 18.5^{\mathrm{a}}$ & $16.7 \pm 4.3^{\mathrm{a}}$ & $20.0 \pm 2.5^{\mathrm{a}}$ & $17.1 \pm 3.8^{\mathrm{a}}$ \\
\hline & $13.0-28.9$ & 10.9-19.7 & $19.8-32.2$ & $11.8-21.5$ & $9.6-76.6$ & $11.5-25.7$ & $17.0-26.3$ & $11.2-23.7$ \\
\hline \multirow[t]{2}{*}{$\mathrm{Fe}$} & $544 \pm 292^{a}$ & $404 \pm 91^{a}$ & $314 \pm 50^{b}$ & $262 \pm 358^{b}$ & $1285 \pm 566^{\mathrm{a}}$ & $593 \pm 117^{a}$ & $314 \pm 59^{b}$ & $157 \pm 107^{b}$ \\
\hline & $235-1806$ & $263-589$ & $219-423$ & $36-2003$ & $587-2208$ & $438-837$ & $249-440$ & $37-390$ \\
\hline \multirow[t]{2}{*}{$M n$} & $5.72 \pm 4.96^{a}$ & $7.66 \pm 5.21^{\mathrm{ac}}$ & $2.24 \pm 0.50^{b}$ & $13.9 \pm 7.16^{c}$ & $9.17 \pm 2.72^{a}$ & $6.82 \pm 1.81^{a}$ & $2.13 \pm 0.32^{b}$ & $14.1 \pm 11.1^{a}$ \\
\hline & $1.72-25.8$ & $2.17-25.8$ & $1.60-4.22$ & $4.17-26.8$ & $5.23-13.7$ & $4.86-12.1$ & $1.73-2.84$ & $1.30-38.1$ \\
\hline \multirow[t]{2}{*}{$\mathrm{Ni}$} & $1.44 \pm 6.63^{\mathrm{a}}$ & $0.66 \pm 0.28^{b c}$ & $0.27 \pm 0.35^{b}$ & $1.01 \pm 0.64^{c}$ & $0.03 \pm 0.02^{\mathrm{a}}$ & $0.57 \pm 0.28^{b c}$ & $0.10 \pm 0.09^{\mathrm{ab}}$ & $1.20 \pm 1.67^{c}$ \\
\hline & $<0.05-35.1$ & $0.18-1.21$ & $<0.04-1.70$ & $0.36-2.38$ & $<0.04-0.55$ & $0.34-1.24$ & $<0.04-0.23$ & $0.42-7.17$ \\
\hline \multirow[t]{2}{*}{ Se } & $12.2 \pm 5.1^{\mathrm{a}}$ & $12.1 \pm 4.7^{\mathrm{a}}$ & $6.9 \pm 3.1^{b}$ & $9.0 \pm 4.6^{\mathrm{ab}}$ & $11.5 \pm 5.6^{a}$ & $10.8 \pm 5.8^{a}$ & $4.3 \pm 1.5^{b}$ & $4.5 \pm 1.9^{b}$ \\
\hline & $4.6-23.8$ & $5.0-19.9$ & 2.1-13.6 & $3.0-25.1$ & 4.4-23.1 & $3.6-24.2$ & $2.5-7.2$ & $1.3-7.4$ \\
\hline \multirow[t]{2}{*}{$\mathrm{Zn}$} & $115 \pm 19^{a}$ & $91 \pm 12^{b}$ & $38 \pm 4^{c}$ & $165 \pm 11^{d}$ & $135 \pm 45^{\mathrm{ac}}$ & $83 \pm 13^{a}$ & $38 \pm 8^{b}$ & $177 \pm 24^{c}$ \\
\hline & $87-188$ & $65-114$ & $30-50$ & $144-188$ & $74-202$ & $67-110$ & $30-60$ & $137-236$ \\
\hline
\end{tabular}

Significant differences between tissues for each trace element and species distinctly are indicated by letters at the level $\alpha=0.05$ (Kruskal-Wallis test). 


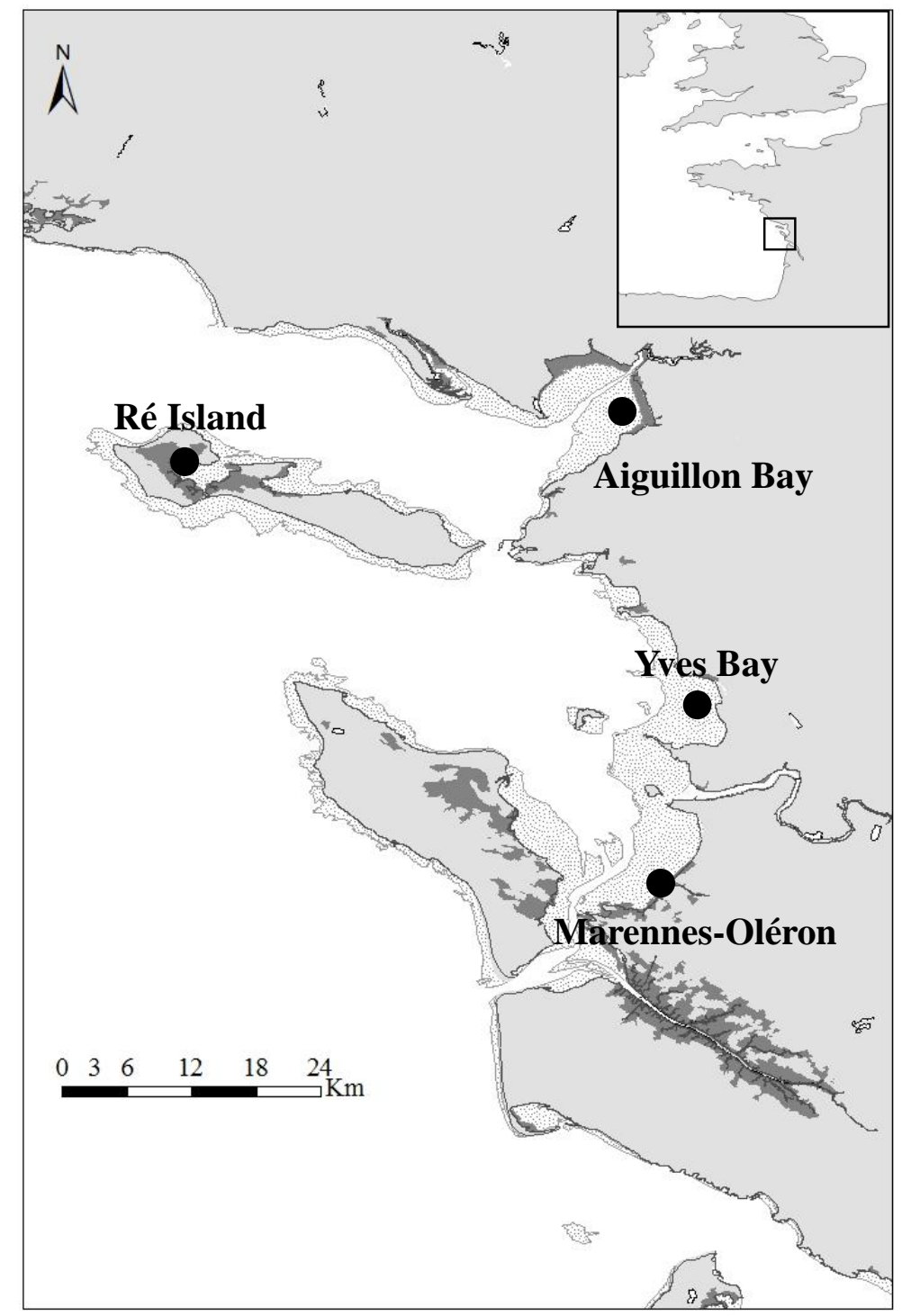

Fig. 1. Map of the Pertuis Charentais on the French Atlantic coast and locations of the sampling sites: Ré Island, Aiguillon Bay, Yves Bay and Marennes-Oléron Bay. 

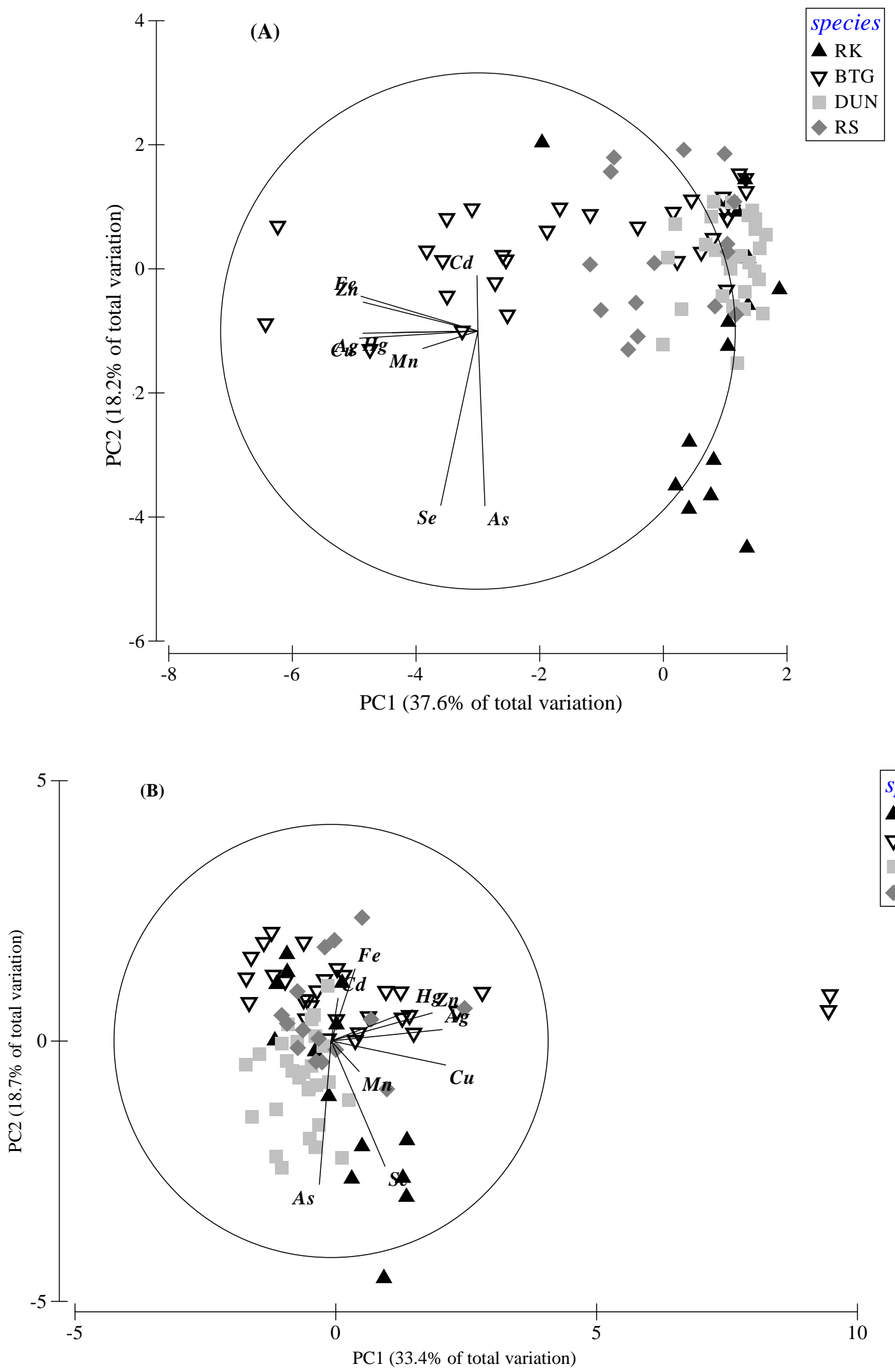

species

$\Delta \mathrm{RK}$

$\boldsymbol{\nabla}$ BTG

DUN

RS 

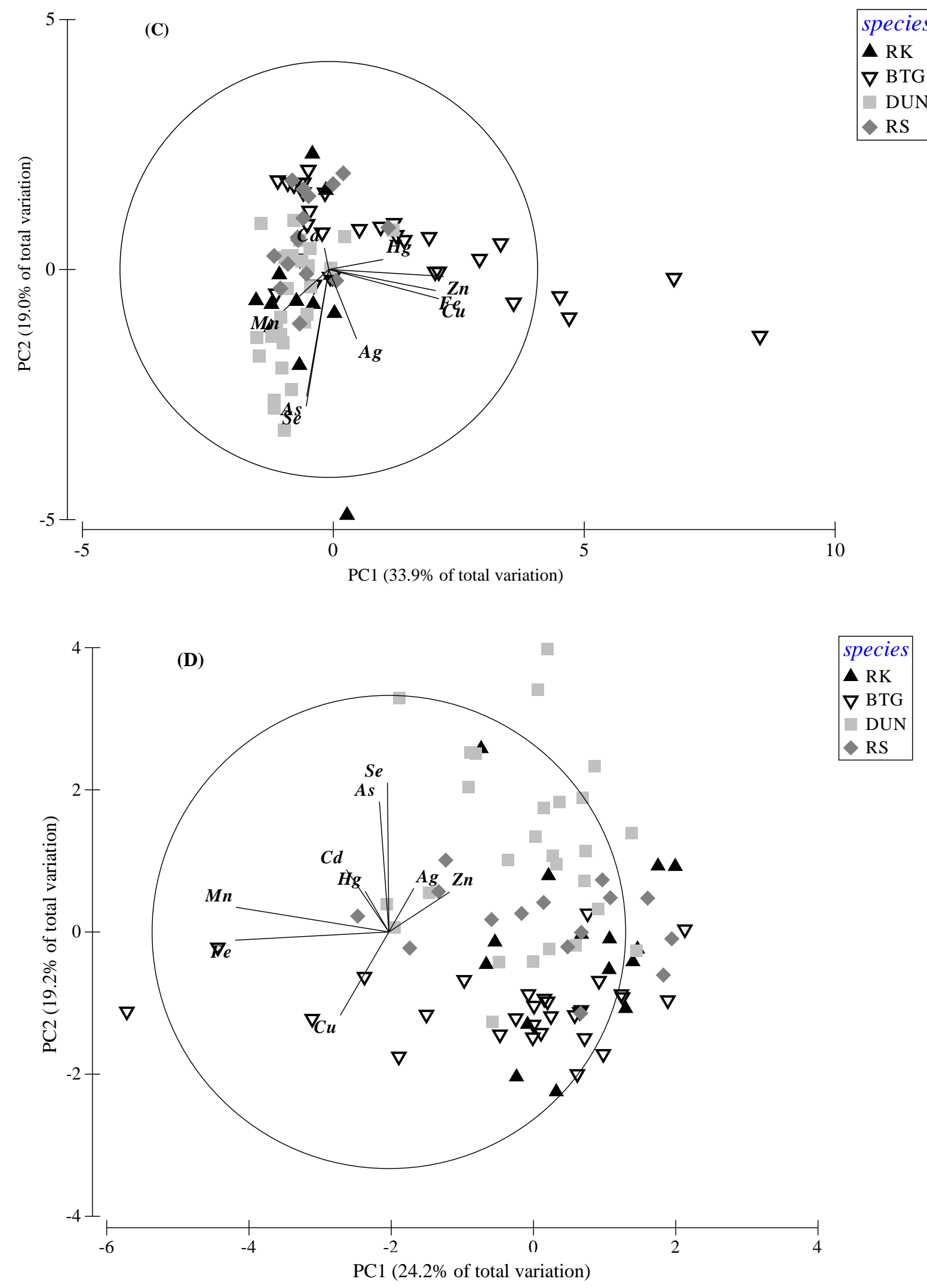

Fig. 2. Principal component analysis based on the trace element concentrations in the liver (A), kidney (B), muscle (C), and feathers (D) of red knots (RK), black-tailed godwits (BTG), dunlins (DUN) and redshanks (RS). For clarity and readability reasons, the center of the correlation circle has been moved on $\mathrm{A}$ and $\mathrm{D}$ graphs from its origin $(\mathrm{X}=0 ; \mathrm{Y}=0)$. 


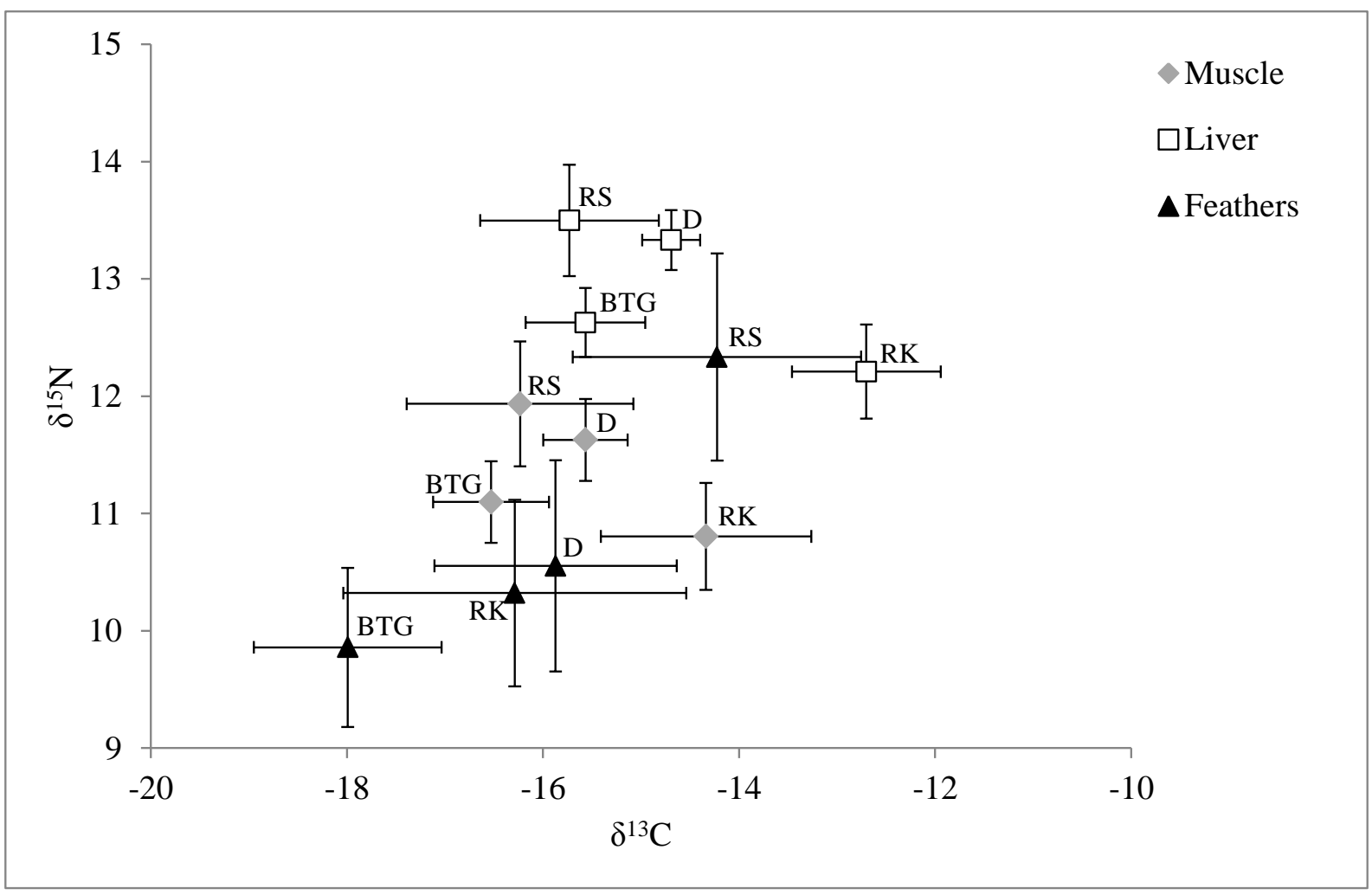

Fig. 3. Carbon $\left(\delta^{13} \mathrm{C}\right)$ and nitrogen $\left(\delta^{15} \mathrm{~N}\right)$ isotopic signatures (mean $\%$ o $\pm \mathrm{SE}$ ) of the liver, muscle and feathers of the Red Knot (RK), Black-tailed Godwit (BTG), Dunlin (D) and Redshank (RS) from the Pertuis Charentais (Atlantic coast of France). 


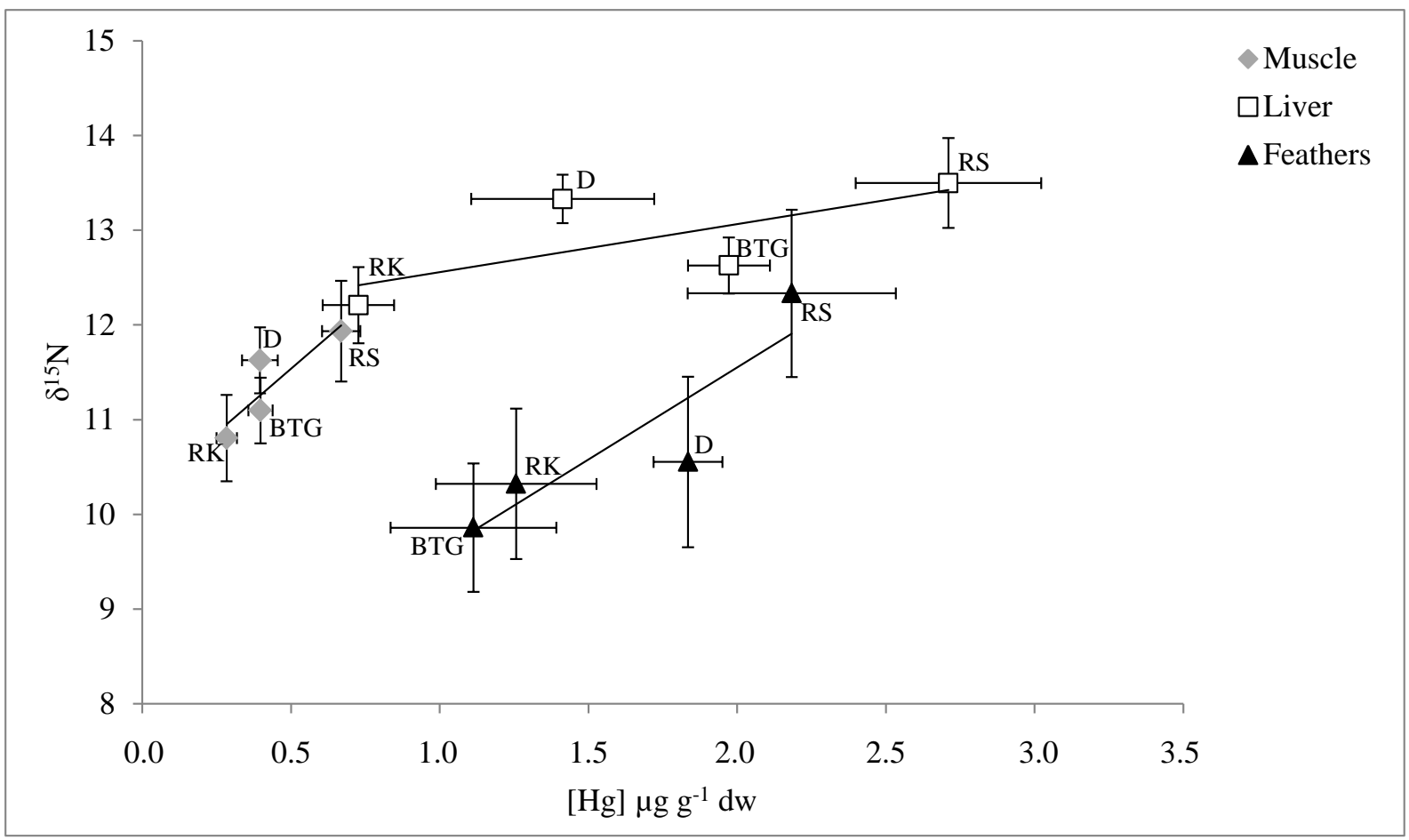

Fig. 4. Relationship between nitrogen $\left(\delta^{15} \mathrm{~N}\right)$ isotopic signatures (mean $\%_{0} \pm \mathrm{SE}$ ) and $\mathrm{Hg}$ concentrations $\left(\mu \mathrm{g} \mathrm{g}^{-1} \pm \mathrm{SE}\right)$ in the liver, muscle and feathers of the Red Knot (RK), Blacktailed Godwit (BTG), Dunlin (D) and Redshank (RS) from the Pertuis Charentais. 

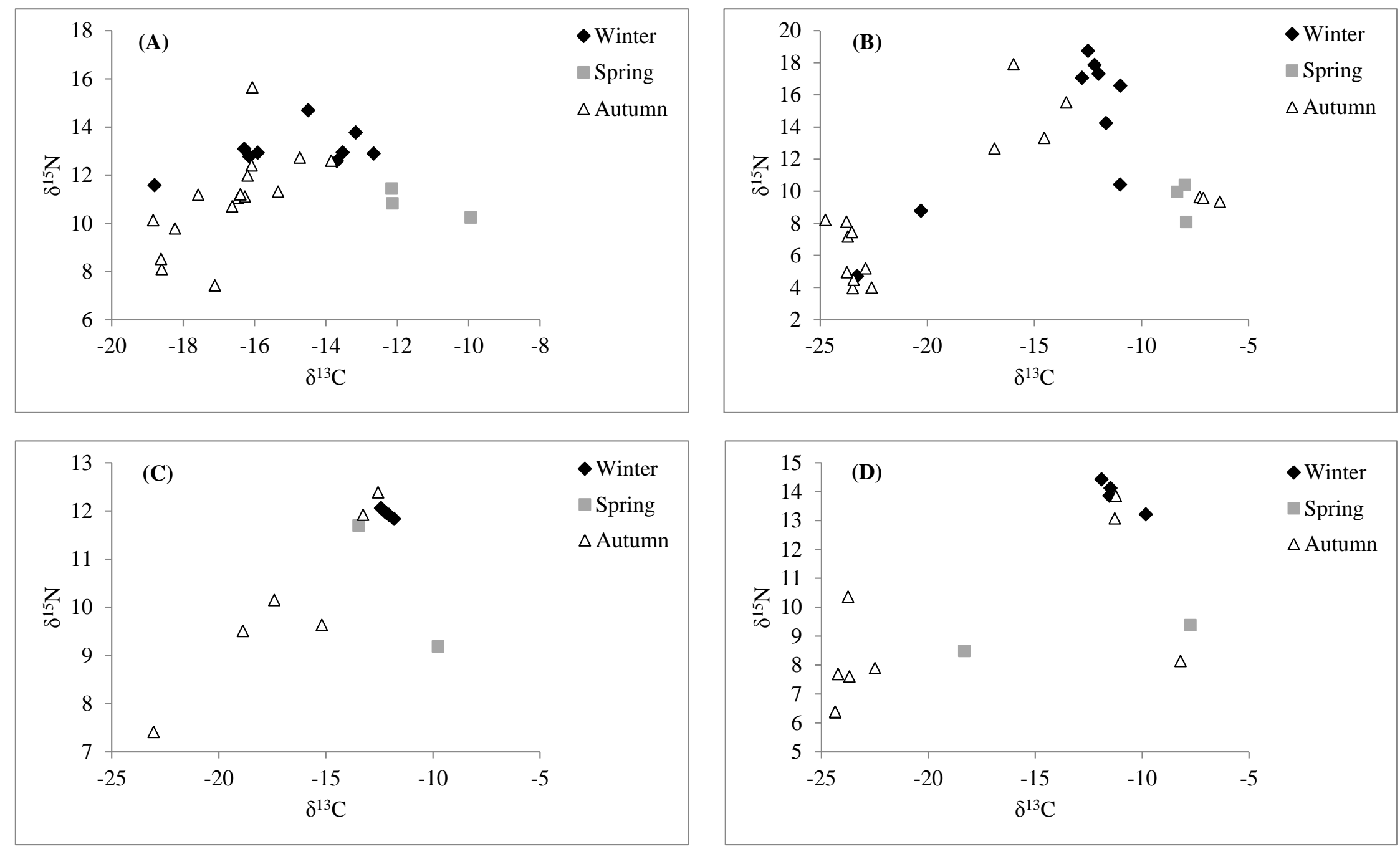


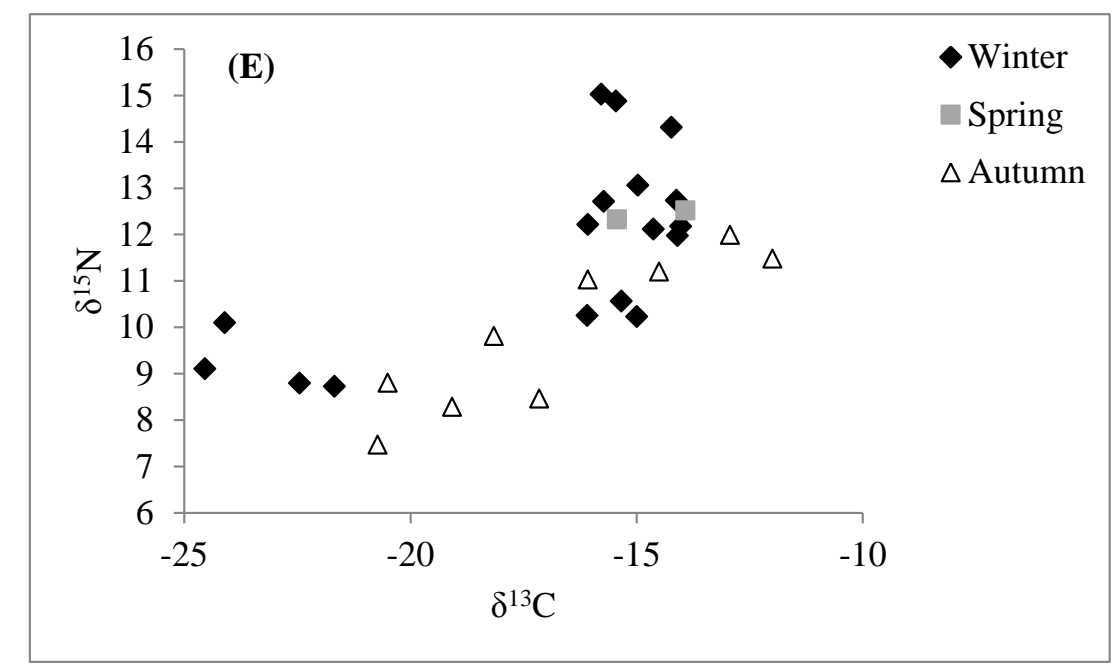

Fig. 5. Carbon $\left(\delta^{13} \mathrm{C}\right)$ and nitrogen $\left(\delta^{15} \mathrm{~N}\right)$ isotopic signatures $(\%)$ of $(\mathrm{A})$ and $(\mathrm{B})$ the muscle and feathers of dunlins, respectively; (C) and (D) the muscle and feathers of red knots, respectively; and (E) the muscle of black-tailed godwits in winter, spring, and autumn. 